\title{
Standardization of Plant Bio-Regulators for In Vitro Shoot Proliferation of Curcuma longa L. Cv. Roma
}

\author{
S. Beura ${ }^{1}$, A. Sahu ${ }^{2}$, S. Rout ${ }^{3}$, R. Beura ${ }^{4}$ and P.N. Jagadev ${ }^{5}$ \\ ${ }^{1}$ Biotechnology-cum-Tissue Culture Centre, Orissa University of Agriculture and Technology, \\ Bhubaneswar-751003, Odisha, India \\ ${ }^{2}$ MITS School of Biotechnology, Bhubaneswar-751024, Odisha, India \\ ${ }^{3}$ College of Forestry, Sam Higginbottom University of Agriculture Technology and Sciences, \\ Allahabad-211007, Uttar Pradesh, India \\ ${ }^{4}$ College of Basic Science and Humanity, Orissa University of Agriculture and Technology, \\ Bhubaneswar-751003, Odisha, India \\ ${ }^{5}$ Dean of Research, Orissa University of Agriculture and Technology, \\ Bhubaneswar-751003, Odisha, India \\ *Corresponding author
}

\begin{tabular}{|c|c|}
\hline & A B S T R A C T \\
\hline & \multirow{4}{*}{$\begin{array}{l}\text { The present investigation was carried out to standardize the plant bio regulators for in vitro } \\
\text { shoot proliferation of Curcuma longa } \mathrm{L} \text {. } \mathrm{Cv} \text {. Roma. The finger tip of the C. longa was } \\
\text { taken as explants and cultured on } \mathrm{MS} \text { media supplemented with different concentrations of } \\
\text { plant bio-regulators. The result showed that the explants surface sterilized with } 70 \% \\
\text { ethanol for } 30 \mathrm{Sec} \text {, followed by } 0.1 \% \mathrm{HgCl}_{2} \text { for } 11 \text { minutes, followed by } 1 \% \mathrm{KCl} \text { washing } \\
\text { for } 1 \mathrm{~min} \text { reduced the fungal } \% \text {, bacterial } \% \text { and death } \% \text {. The similar treatment recorded } \\
\text { highest survival }(90 \%) \text { and aseptic }(90 \%) \text {, minimum days to bud emergence }(11.31) \text {, } \\
\text { maximum available days to bud elongation. MS media supplemented with BAP }(3.0 \mathrm{mg} / \mathrm{l}) \text {, } \\
\mathrm{NAA}(0.2 \mathrm{mg} / \mathrm{l}) \text { and } \mathrm{GA}_{3}(0.2 \mathrm{mg} / \mathrm{l}) \text { produces longer bud }(0.7 \mathrm{~cm}) \text {. This protocol can be } \\
\text { very useful to the future research worker and as well as entrepreneurs for mass production } \\
\text { of Curcuma Longa L. Cv. Roma. }\end{array}$} \\
\hline $\begin{array}{l}\text { Bud, } \\
\text { Curcuma longa, } \\
\text { explants, Shoot. }\end{array}$ & \\
\hline Article Info & \\
\hline $\begin{array}{l}\text { Accepted: } \\
\text { 04 April } 2017 \\
\text { Available Online: } \\
10 \text { May } 2017\end{array}$ & \\
\hline
\end{tabular}

\section{Introduction}

Turmeric is one of the most important and ancient spices of India and a traditional item of export. It belongs to family Zingiberaceae and is a commercial crop of tropics. It is a perennial, herbaceous plant valuable for its underground rhizome which is used as spice, pigment and medicine. It is cultivated extensively in India, Srilanka, parts of China, Indo China and Pakistan. India is a largest producer and exporter of turmeric with an annual production of 6.59 lakh tones. But the main turmeric growing states are Andhra Pradesh, Maharashtra, Odisha, Tamil Nadu and Karnataka, etc.

In addition to its use as a spice, it has other religious uses in connection with marriage and death. A small fraction of turmeric is also used in the field of medicine, cosmetics and in dying of textile fabrics. Turmeric powder from turmeric and its main component, curcumin have a wide range of medicinal and 
culinary uses. Curry powder usually contains about $24 \%$ of turmeric powder. Turmeric is also used as a dye and as an ingredient in the preparation of medicinal oils, ointments and poultice. It is a stomachic, carminative tonic, blood purifier, vermicide and an antiseptic. Turmeric is useful in treating gall stones and gall complaints. It is also used for diarrhea, dropsy, Jaundice, liver disorder, urinary troubles etc, besides this turmeric is also used as cosmetic, perfumery and medicine formulations (Gomathy et al., 2014).

As turmeric is used as a dying agent, it was usually used in India for dying wool, silk and cotton. However, it is now restricted for dying cotton. The dye is also used as a colouring material in pharmacy, confectionary, rice milling and food industries. Turmeric paper is an official reagent in British pharmacopeia for testing alkalinity. Turmeric is widely used as a flavoring and a colourant during the preparation of butter, cheese, margarine, pickles, fruits stuffs liquor, fruit drinks, , cakes and table jellies. The volatile oil derived from stem distillation of turmeric rhizome is an orange-yellow liquid. The dried rhizome yields 5-6\% essential oil and fresh one gives $0.24 \%$ essential oil (Krishnamurthy et al., 1975). The essential oil of turmeric is antiseptic in nature.

The high-value crop turmeric is propagated vegetatively through mother rhizomes and fingers. The multiplication rate is very slow in finger and rhizome containing a single bud, give rise to a single plant only in vivo condition. These underground structures are exposed to natural hazardous conditions, so the risk of infection is more. Therefore, it is essential to find out an alternative method of propagation for by passing the slow rate of multiplication which also reduces the cost of transportation and planting by hulking up true to type disease free stocks of high yielding new cultivars within a shorter period. Though some attempts have been made towards in vitro multiplication of turmeric (Nadgauda et al., 1978; Sunitibala et al., 2001 and Salvi et al., 2002), still the work is meager. The present investigation was carried out in high yielding OUAT, released cultivar of Odisha such as Roma, with the following objectives to standardize the surface sterilant for maximum survival percentage and the plant bio-regulators for shoot proliferation.

\section{Materials and Methods}

The present experiments were carried out at the plant tissue culture laboratory, Department of Horticulture, College of Agriculture, OUAT, Bhubaneswar during the session 2007-08.

\section{Plant material}

For the present investigation on the in vitro shoot proliferation of Curcuma longa L., the rhizome was procured from High Altitude Research Station, OUAT, Pottangi, Koraput, Odisha

\section{Explants}

The finger tips of turmeric were taken as explants for the experiment on in vitro study.

\section{Stock solution, media preparation and sterilization}

The chemicals used for the present study were analytical reagents of excel $\mathrm{R}$ grade of Titan Biotech Ltd., Ranbaxy Laboratory Ltd., Merck (India), Qualigen Fine Chemicals, and Himedia Laboratories Ltd. (India). Auxins, Cytokinins, myo-inositol and Fe-EDTA were supplied by Sigma (USA) and Agar from Ranbaxy Laboratory Limited. MS Medium (Murashige and Skoog, 1962) was used throughout the investigation, required quantities of macronutrients, micronutrients, 
Fe-EDTA, vitamins and plant bioregulators were taken from the stock solution and required quantity of sucrose dissolved in distilled water was added fresh to the medium. The $\mathrm{pH}$ of the solution was adjusted to $5.7 \pm 0.1$ using $0.1 \mathrm{~N} \mathrm{NaOH}$ or $0.1 \mathrm{~N} \mathrm{HCL}$. Then volume was made up to $1 \mathrm{~L}$ with distilled water. Agar $(0.6 \% \mathrm{w} / \mathrm{v})$ was added to the medium boiled and poured into the culture tube and plugged. Culture tubes containing culture medium were autoclaved for the 20 minutes at $121^{\circ} \mathrm{C}$ and 15 Psi pressure.

The autoclaved medium was kept in a laminar air flow bench for cooling. All the glassware were dipped in the detergent solution for overnight and washed under running tap water. They were rinsed with distilled water and then dried in an oven for $2 \mathrm{hrs}$ at $150^{\circ} \mathrm{C}$. Forceps, Petridis and scalpel were thoroughly cleaned with isopropanol or rapped with paper and kept in a clean sterilized in the autoclave at $15 \mathrm{psi}$ and $121^{\circ} \mathrm{C}$ for 20 minutes. The working chamber of laminar air flow cabinet was wiped with isopropanol. Filtered air (80-100 cft $/ \mathrm{min})$ to ensure that particles do not settle in working area was blown for 5 minutes. The sterilized materials to be used (except living tissue) were kept in the chamber and exposed to UV light for 30 minutes.

\section{Inoculation}

The explants were collected for turmeric plants raised in High Altitude Research Station, OUAT, Pottangi, Koraput, Odisha. Rhizomes were lifted from the soil and washed with water to make free of soil, dirt particles and dried under shade. Freshly harvested $C$. longa in the month of February was used as explants. The tip of the fingers containing dormant buds $(0.2-0.5 \mathrm{~cm}$ thickness) was excised after pulling the scaly leaves for in vitro study.
The explants were collected from turmeric by the help of a clean razor blade and collected in the beaker containing tap waters. Then these explants were kept in a $250 \mathrm{ml}$ beaker containing $0.02 \%$ Bavistin and Streptocycline solution for 15 minutes. The explants were washed under running tap water followed by distilled water, for thorough rinsing. The explants were carefully inoculated to the MS medium containing plant bioregulators (Table 3) for shooting. Three replications per treatment and 3 culture bottles per replication were marked for observation

\section{Culture room}

The cultures were kept $25+2^{\circ} \mathrm{C}$ in an air conditioned room with a 16 hour photoperiod (3000-3200 lux) supplied by fluorescent tubes and $80 \%$ relative humidity.

\section{Standardization of surface sterilants}

The explants were surface sterilized with different sterilants at various concentrations and duration under the laminar air flow cabinet. The explants were surface sterilized with $70 \%$ Ethyl alcohol (30 sec),followed by $01 \% \mathrm{HgCl}_{2}(3,5,7,9,11,13,15,17$, and 19 min.) followed by autoclaved $1 \% \mathrm{KCl} \operatorname{dip}(1 \mathrm{~min}$.) to remove the excess $\mathrm{Hg}++$ ions.

After surface sterilization, the explants were rinsed 3-4 times in sterilized distilled water and dried on an autoclaved filter paper (Table 2).

The observations on the percentage of Contamination (fungal and bacterial), the percentage of aseptic culture, percentage of death and survival were recorded at a timely interval. The days taken for bud emergence, available days for bud elongation and a number of buds per explants at 28 DAI (Days after inoculation) were also recorded. 
Standardization of plant bio regulators for culture establishment

For culture establishment study, the explants were treated with its best sterilants and were inoculated into the MS medium containing different concentrations of Cytokinin (BAP), auxins (NAA) and gibberellic acid $\left(\mathrm{GA}_{3}\right)$ (Table 3). Observations on the number of multiple buds per explants and shoot length were recorded in 21 days after inoculation

\section{Statistical analysis}

The raw data obtained during the experimental observations were subjected to statistical analysis as per method by Gomez and Gomez, (1984). The significance and notsignificance of the treatment effect were judged with the help of ' $F$ ' variance ratio test. Calculated ' $\mathrm{F}$ ' value was compared with the table value of ' $F$ ' at $5 \%$ level of significance. The data were transferred from where ever required before suitability of Analysis of Variance (ANOVA) analyzed in statistical package SAS version 7.0.

\section{Results and Discussion}

For surface sterilization study of $C$. longa, $\mathrm{Cv}$. Roma, the explants surface sterilized with $70 \%$ Ethanol followed by $0.1 \% \mathrm{HgCl}_{2}$ (11 min),followed by $1 \% \mathrm{KCl}(1 \mathrm{Min})$ revealed significantly the fungal infection $(10 \%)$, bacterial infection $(0 \%)$ and death $(0 \%)$.

Significantly maximum fungal infection was recorded in control and significantly maximum contamination was recorded with $70 \%$ ethanol (30 sec.) followed by $0.1 \%$ $\mathrm{HgCl}_{2}$ (3, 5 min.) followed by $1 \% \mathrm{KCl}(1$ Min.). The finger tip explants of Curcuma longa $\mathrm{L}$. Cv. Roma surface sterilized with 70 $\%$ Ethanol for $30 \mathrm{sec}$., followed by $0.1 \%$ $\mathrm{HgCl}_{2}$ (11 Min), followed by $1 \% \mathrm{KC} 1$ (1 min) reduced the fungal infection and bacterial infection, no death and increased the percentage of aseptic culture and survival of the explant. Early bud emergence, available days for bud elongation and each and every explant capable of producing bud were recorded with this treatment. Not a single explant was survived when no sterilant was used similar results were also reported by Palai (2001) and Rahman et al., (2004). Ethylalcohol along with $\mathrm{HgCl}_{2}$ was used as a surface sterilant in Gladiolus by Beura, (1998).

The treatment significantly increased the survival percentage (90\%) and aseptic culture (90\%). The explants was surface sterilized with $70 \%$ Ethanol $(30 \mathrm{sec}$.) followed by $0.1 \%$ $\mathrm{Hgcl}_{2}(11 \mathrm{~min})$ followed by $1 \% \mathrm{KCl}(11$ Min) significantly reduced the days to bud emergence (11.3), increased the available days for bud elongation (16.67 days) and each explants produced a bud (1.0) (Table 6).

\section{Culture establishment}

The results of table 6 indicated that for culture establishment of finger tip explants of $C$. longa $\mathrm{Cv}$. Roma, MS medium alone and in combinations with BAP $(2.0,2.5,3.0 \mathrm{mg} / \mathrm{l})$, NAA $(0.1,0.2,0.3 \mathrm{mg} / \mathrm{l})$ and $\mathrm{GA}_{3}(0.2 \mathrm{mg} / \mathrm{l})$ were used. The results revealed that BAP (2.5mg and $3.0 \mathrm{mg} / \mathrm{l})$ with $\mathrm{GA}_{3}(0.2 \mathrm{mg} / \mathrm{l})$ and BAP $(2.0,2.5,2.0 \mathrm{mg} / \mathrm{l})$, NAA $(0.1,0.2,0.3$ $\mathrm{mg} / \mathrm{l}) \quad$ with $\mathrm{GA}_{3} \quad(0.2 \mathrm{mg} / \mathrm{l})$ Produced significantly maximum number of buds / explants (1.0), then MS medium alone (0.33) and BAP $(2.0 \mathrm{mg} / \mathrm{l})$ with $\mathrm{GA}_{3}(0.2 \mathrm{mg} / \mathrm{l})$ producing 0.67 number of buds per explants. Significantly maximum bud length $(0.7 \mathrm{~cm})$ was recorded with BAP $(3.0 \mathrm{mg} / \mathrm{l})$ with NAA and $\mathrm{GA}_{3}$ each with $0.2 \mathrm{mg} / \mathrm{l}$. Minimum bud length $(0.3 \mathrm{~cm})$ was recorded in MS medium only. The dormant tips explants of $C$. longa Cv. Roma were cultured on MS medium supplemented with various levels of BAP, NAA with $0.2 \mathrm{mg} / 1 \quad \mathrm{GA}_{3}$ for culture establishment. 
Table.1 The salient feature of Curcuma longa L. Cv. Roma

\begin{tabular}{|c|l|l|}
\hline Sl. No. & Characteristics & \multicolumn{1}{|c|}{ Crops with cultivars } \\
\cline { 3 - 3 } & & Curcuma longa L. Cv. Roma \\
\hline 1 & Rhizome & Round mother \\
\hline 2 & Skin Colour & Orange yellow \\
\hline 3 & Scale & Brown \\
\hline 4 & Tolerant to & Leaf blotch leaf spot and scale insect \\
\hline 5 & Duration & 250 days \\
\hline 6 & Average yield & 20.70 t/ha \\
\hline 7 & Potential yield & 40.0 t/ha \\
\hline 8 & Dry recovery & $31.0 \%$ \\
\hline 9 & Oleoresin & $13.2 \%$ \\
\hline 10 & Essential oil & $4.2 \%$ \\
\hline 11 & Curcumin & 9.3 \\
\hline
\end{tabular}

Table.2 Details of surface sterilants Curcuma longa L. Cv. Roma

\begin{tabular}{|c|c|}
\hline $\mathrm{T}_{1}$ & Tap Water \\
\hline $\mathrm{T}_{2}$ & Dipped in $70 \%$ Ethanol (30sec) $+0.1 \% \mathrm{HgCl}_{2}(3 \mathrm{Min})+1 \% \mathrm{KCl}(1 \mathrm{Min})$ \\
\hline $\mathrm{T}_{3}$ & Dipped in $70 \%$ Ethanol (30 Sec) $+0.1 \% \mathrm{HgCl}_{2}(5 \mathrm{Min})+1 \% \mathrm{KCl}(1 \mathrm{Min})$ \\
\hline $\mathrm{T}_{4}$ & Dipped in $70 \%$ Ethanol $(30 \mathrm{sec})+0.1 \% \mathrm{HgCl}_{2}(7 \mathrm{Min})+1 \% \mathrm{KCl}(1 \mathrm{Min})$ \\
\hline $\mathrm{T}_{5}$ & Dipped in $70 \%$ Ethanol $(30 \mathrm{Sec})+0.1 \% \mathrm{HgCl}_{2}(9 \mathrm{Min})+1 \% \mathrm{KCl}(1 \mathrm{Min})$ \\
\hline $\mathrm{T}_{6}$ & Dipped in $70 \%$ Ethanol (30sec) $+0.1 \% \mathrm{HgCl}_{2}(11 \mathrm{Min})+1 \% \mathrm{KCl}(1 \mathrm{Min})$ \\
\hline $\mathrm{T}_{7}$ & Dipped in $70 \%$ Ethanol $(30 \mathrm{Sec})+0.1 \% \mathrm{HgCl}_{2}(13 \mathrm{Min})+1 \% \mathrm{KCl}(1 \mathrm{Min})$ \\
\hline $\mathrm{T}_{8}$ & Dipped in $70 \%$ Ethanol (30sec) $+0.1 \% \mathrm{HgCl}_{2}(15 \mathrm{Min})+1 \% \mathrm{KCl}(1 \mathrm{Min})$ \\
\hline $\mathrm{T}_{9}$ & Dipped in $70 \%$ Ethanol $(30 \mathrm{Sec})+0.1 \% \mathrm{HgCl}_{2}(17 \mathrm{Min})+1 \% \mathrm{KCl}(1 \mathrm{Min})$ \\
\hline $\mathrm{T}_{10}$ & Dipped in $70 \%$ Ethanol (30sec) $+0.1 \% \mathrm{HgCl}_{2}(19 \mathrm{Min})+1 \% \mathrm{KCl}(1 \mathrm{Min})$ \\
\hline
\end{tabular}

Table.3 Details of Concentration of BAP, NAA and $\mathrm{GA}_{3}$ for culture Establishment of Curcuma longa L. Cv. Roma

\begin{tabular}{|c|c|c|c|}
\hline Treatments & $\mathbf{B A P}(\mathbf{m g} / \mathbf{l})$ & $\mathbf{N A A}(\mathbf{m g} / \mathbf{l})$ & $\mathbf{G A}_{3}(\mathbf{m g} / \mathbf{l})$ \\
\hline $\mathrm{T}_{1}($ MS Medium $)$ & - & - & - \\
\hline $\mathrm{T}_{2}$ & 2.0 & - & 0.2 \\
\hline $\mathrm{T}_{3}$ & 2.5 & - & 0.2 \\
\hline $\mathrm{T}_{4}$ & 3.0 & - & 0.2 \\
\hline $\mathrm{T}_{5}$ & 2.0 & 0.1 & 0.2 \\
\hline $\mathrm{T}_{6}$ & 2.5 & 0.1 & 0.2 \\
\hline $\mathrm{T}_{7}$ & 3.0 & 0.1 & 0.2 \\
\hline $\mathrm{T}_{8}$ & 2.0 & 0.2 & 0.2 \\
\hline $\mathrm{T}_{9}$ & 2.5 & 0.2 & 0.2 \\
\hline $\mathrm{T}_{10}$ & 3.0 & 0.2 & 0.2 \\
\hline $\mathrm{T}_{11}$ & 2.0 & 0.3 & 0.2 \\
\hline $\mathrm{T}_{12}$ & 2.5 & 0.3 & 0.2 \\
\hline $\mathrm{T}_{13}$ & 3.0 & 0.3 & 0.2 \\
\hline
\end{tabular}


Table.4 Effect of surface sterilants on the level of Contamination, Survival and aseptic culture in Curcuma longa L. Cv. Roma

\begin{tabular}{|c|c|c|c|c|c|c|}
\hline \multicolumn{2}{|c|}{ Treatments } & \multirow{2}{*}{ 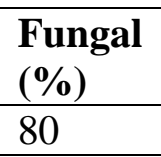 } & \multirow{2}{*}{$\begin{array}{l}\begin{array}{l}\text { Bacterial } \\
(\%)\end{array} \\
20 \\
\end{array}$} & \multirow{2}{*}{$\begin{array}{l}\begin{array}{l}\text { Death } \\
(\%)\end{array} \\
0 \\
\end{array}$} & \multirow{2}{*}{\begin{tabular}{|l|}
$\begin{array}{l}\text { Survival } \\
(\%)\end{array}$ \\
0 \\
\end{tabular}} & \multirow{2}{*}{\begin{tabular}{|l} 
Aseptic \\
$(\%)$
\end{tabular}} \\
\hline $\mathrm{T}_{1}$ & Tap Water & & & & & \\
\hline $\mathrm{T}_{2}$ & $\begin{array}{l}\text { Dipped in } 70 \% \text { Ethanol }(30 \mathrm{sec})+0.1 \% \mathrm{HgCl}_{2}(3 \mathrm{Min})+1 \% \mathrm{KCl}(1 \\
\text { Min) }\end{array}$ & 70 & 30 & 0 & 0 & 0 \\
\hline $\mathrm{T}_{3}$ & $\begin{array}{l}\text { Dipped in } 70 \% \text { Ethanol (30 Sec) }+0.1 \% \mathrm{HgCl}_{2}(5 \mathrm{Min})+1 \% \mathrm{KCl}(1 \\
\text { Min) }\end{array}$ & 60 & 30 & 0 & 10 & 10 \\
\hline $\mathrm{T}_{4}$ & $\begin{array}{l}\text { Dipped in } 70 \% \text { Ethanol }(30 \mathrm{sec})+0.1 \% \mathrm{HgCl}_{2} \text { (7Min) }+1 \% \mathrm{KCl}(1 \\
\text { Min) }\end{array}$ & 30 & 20 & 0 & 50 & 50 \\
\hline $\mathrm{T}_{5}$ & $\begin{array}{l}\text { Dipped in } 70 \% \text { Ethanol }(30 \mathrm{Sec})+0.1 \% \mathrm{HgCl}_{2}(9 \mathrm{Min})+1 \% \mathrm{KCl}(1 \\
\text { Min) }\end{array}$ & 20 & 10 & 0 & 70 & 70 \\
\hline $\mathrm{T}_{6}$ & $\begin{array}{l}\text { Dipped in } 70 \% \text { Ethanol }(30 \mathrm{sec})+0.1 \% \mathrm{HgCl}_{2}(11 \mathrm{Min})+1 \% \mathrm{KCl}(1 \\
\text { Min) }\end{array}$ & 10 & 0 & 0 & 90 & 90 \\
\hline $\mathrm{T}_{7}$ & $\begin{array}{l}\text { Dipped in } 70 \% \text { Ethanol }(30 \mathrm{Sec})+0.1 \% \mathrm{HgCl}_{2}(13 \mathrm{Min})+1 \% \mathrm{KCl} \\
\text { (1 Min) }\end{array}$ & 40 & 0 & 20 & 40 & 60 \\
\hline $\mathrm{T}_{8}$ & $\begin{array}{l}\text { Dipped in } 70 \% \text { Ethanol }(30 \mathrm{sec})+0.1 \% \mathrm{HgCl}_{2}(15 \mathrm{Min})+1 \% \mathrm{KCl}(1 \\
\text { Min) }\end{array}$ & 30 & 0 & 40 & 30 & 70 \\
\hline $\mathrm{T}_{9}$ & $\begin{array}{l}\text { Dipped in } 70 \% \text { Ethanol }(30 \mathrm{Sec})+0.1 \% \mathrm{HgCl}_{2}(17 \mathrm{Min})+1 \% \mathrm{KCl} \\
(1 \mathrm{Min})\end{array}$ & 50 & 0 & 20 & 30 & 50 \\
\hline \multirow[t]{3}{*}{$\mathrm{T}_{10}$} & $\begin{array}{l}\text { Dipped in } 70 \% \text { Ethanol (30sec) }+0.1 \% \mathrm{HgCl}_{2}(19 \mathrm{Min})+1 \% \mathrm{KCl}(1 \\
\text { Min) }\end{array}$ & 30 & 0 & 20 & 50 & 70 \\
\hline & $\mathrm{SE}(\mathbf{m}) \pm$ & 2.09 & 1.71 & 1.09 & 2.34 & 1.61 \\
\hline & CD at (5\%) & 6.02 & 4.90 & 3.13 & 6.71 & 4.62 \\
\hline
\end{tabular}


Table.5 Effect of surface sterilant on days to bud emergence, available days for bud elongation and number of buds/ explant of Curcuma longa L. Cv. Roma

\begin{tabular}{|c|c|c|c|c|}
\hline \multicolumn{2}{|r|}{ Treatments } & \multirow{2}{*}{$\begin{array}{c}\text { Days to } \\
\text { Bud } \\
\text { Emergence } \\
0\end{array}$} & \multirow{2}{*}{$\begin{array}{c}\text { Available days for } \\
\text { bud } \\
\text { elongation }\end{array}$} & \multirow{2}{*}{$\begin{array}{c}\text { Number of } \\
\text { buds/explant } \\
0\end{array}$} \\
\hline $\mathrm{T}_{1}$ & Tap Water & & & \\
\hline $\mathrm{T}_{2}$ & Dipped in $70 \%$ Ethanol $(30 \mathrm{sec})+0.1 \% \mathrm{HgCl}_{2}(3 \mathrm{Min})+1 \% \mathrm{KCl}(1 \mathrm{Min})$ & 0 & 0 & 0 \\
\hline $\mathrm{T}_{3}$ & Dipped in $70 \%$ Ethanol $(30 \mathrm{Sec})+0.1 \% \mathrm{HgCl}_{2}(5 \mathrm{Min})+1 \% \mathrm{KCl}(1 \mathrm{Min})$ & 12.67 & 15.33 & 0 \\
\hline $\mathrm{T}_{4}$ & Dipped in $70 \%$ Ethanol (30sec) $+0.1 \% \mathrm{HgCl}_{2}(7 \mathrm{Min})+1 \% \mathrm{KCl}(1 \mathrm{Min})$ & 12.00 & 16.00 & 0 \\
\hline $\mathrm{T}_{5}$ & Dipped in $70 \%$ Ethanol (30 Sec) $+0.1 \% \mathrm{HgCl}_{2}(9 \mathrm{Min})+1 \% \mathrm{KCl}(1 \mathrm{~min})$ & 11.33 & 16.67 & 1 \\
\hline $\mathrm{T}_{6}$ & Dipped in $70 \%$ Ethanol (30sec) $+0.1 \% \mathrm{HgCl}_{2}(11 \mathrm{Min})+1 \% \mathrm{KCl}(1 \mathrm{Min})$ & 11.33 & 16.68 & 1 \\
\hline $\mathrm{T}_{7}$ & Dipped in $70 \%$ Ethanol $(30 \mathrm{Sec})+0.1 \% \mathrm{HgCl}_{2}(13 \mathrm{Min})+1 \% \mathrm{KCl}(1 \mathrm{Min})$ & 11.67 & 13.67 & 1 \\
\hline $\mathrm{T}_{8}$ & Dipped in $70 \%$ Ethanol $(30 \mathrm{sec})+0.1 \% \mathrm{HgCl}_{2}(15 \mathrm{Min})+1 \% \mathrm{KCl}(1 \mathrm{Min})$ & 12.00 & 16.00 & 0 \\
\hline $\mathrm{T}_{9}$ & Dipped in $70 \%$ Ethanol $(30 \mathrm{Sec})+0.1 \% \mathrm{HgCl}_{2}(17 \mathrm{Min})+1 \% \mathrm{KCl}(1 \mathrm{Min})$ & 12.33 & 15.67 & 0 \\
\hline \multirow[t]{3}{*}{$\mathrm{T}_{10}$} & Dipped in $70 \%$ Ethanol (30sec) $+0.1 \% \mathrm{HgCl}_{2}(19 \mathrm{Min})+1 \% \mathrm{KCl}(1 \mathrm{Min})$ & 12.67 & 15.33 & 0 \\
\hline & $\mathrm{SE}(\mathbf{m}) \pm$ & 0.09 & 0.19 & 0.079 \\
\hline & CD at $(5 \%)$ & 0.26 & 0.57 & 0.228 \\
\hline
\end{tabular}


Table.6 Effect of BAP, NAA and $\mathrm{GA}_{3}$ on culture establishment of finger tip explants of Curcuma longa L. Cv. Roma

\begin{tabular}{|c|c|c|c|c|c|}
\hline \multicolumn{3}{|c|}{ Treatments (MS medium supplemented)with } & \multirow{2}{*}{$\begin{array}{c}\mathbf{G A}_{3} \\
(\mathbf{m g} / \mathbf{l})\end{array}$} & \multirow{2}{*}{$\begin{array}{l}\text { No. of multiple } \\
\text { buds /explants }\end{array}$} & \multirow{2}{*}{$\begin{array}{c}\text { Bud } \\
\text { length } \\
\text { (cm) }\end{array}$} \\
\hline Sl. No & $\begin{array}{c}\text { BAP } \\
(\mathrm{mg} / \mathrm{l})\end{array}$ & $\begin{array}{l}\text { NAA } \\
(\mathrm{mg} / \mathrm{l})\end{array}$ & & & \\
\hline $\begin{array}{c}\mathrm{T}_{1}(\mathrm{MS} \\
\text { Medium) }\end{array}$ & - & - & - & 0.33 & 0.3 \\
\hline $\mathrm{T}_{2}$ & 2.0 & - & 0.2 & 0.67 & 0.4 \\
\hline$T_{3}$ & 2.5 & - & 0.2 & 1.0 & 0.4 \\
\hline $\mathrm{T}_{4}$ & 3.0 & - & 0.2 & 1.0 & 0.5 \\
\hline$T_{5}$ & 2.0 & 0.1 & 0.2 & 1.0 & 0.4 \\
\hline $\mathrm{T}_{6}$ & 2.5 & 0.1 & 0.2 & 1.0 & .5 \\
\hline $\mathrm{T}_{7}$ & 3.0 & 0.1 & 0.2 & 1.0 & 0.5 \\
\hline $\mathrm{T}_{8}$ & 2.0 & 0.2 & 0.2 & 1.0 & 0.5 \\
\hline $\mathrm{T}_{9}$ & 2.5 & 0.2 & 0.2 & 1.0 & 0.6 \\
\hline $\mathrm{T}_{10}$ & 3.0 & 0.2 & 0.2 & 1.0 & 0.7 \\
\hline $\mathrm{T}_{11}$ & 2.0 & 0.3 & 0.2 & 1.0 & 0.5 \\
\hline $\mathrm{T}_{12}$ & 2.5 & 0.3 & 0.2 & 1.0 & 0.6 \\
\hline $\mathrm{T}_{13}$ & 3.0 & 0.3 & 0.2 & 1.0 & 0.6 \\
\hline SE(m) \pm & & & & 0.05 & 0.02 \\
\hline CD at $(5 \%)$ & & & & $\mathbf{0 . 1 3}$ & 0.06 \\
\hline
\end{tabular}

The results showed that BAP $(3.0 \mathrm{mg} / 1)$, with NAA $(0.2 \mathrm{mg} / 1)$ and $\mathrm{GA}_{3}(0.2 \mathrm{mg} / 1)$ forced all the explants to produce bud, where as the explants cultured on MS medium only produced minimum number of buds/explant (0.33). Significantly maximum bud length $(0.7 \mathrm{~cm})$ was observed in $\mathrm{MS}$ medium supplemented with BAP $(3.0 \mathrm{mg} / 1)$, NAA $(0.2 \mathrm{mg} / 1)$ and $\mathrm{GA}_{3}(0.2 \mathrm{mg} / 1)$. Increased in concentration of BAP $(2.0 \mathrm{mg} / 1$ to $3 \mathrm{mg} / 1)$ along with NAA and $\mathrm{GA}_{3}$ both at $0.2 \mathrm{mg} / 1$ increased the bud length of the cultivar Roma.

Combinations of BAP with NAA for in vitro shoot multiplication of turmeric were reported by Sunitibala et al., (2001) and Salvi et al., 2001). The influence of cytokinin on breaking the dormancy of axillary buds under in vitro condition was reported in various bulbous plants like Tilium and Narcissus (Hussey, 1976). Application of $\mathrm{GA}_{3}$ to $\mathrm{MS}$ medium containing BAP and NAA elongated the dormant axillary bud present at the finger tip the stimulatory effect of $\mathrm{GA}_{3}$ in, elongation of explant is possible due to the fact that $\mathrm{GA}_{3}$ promotes both cell division and cell elongation in sub apical zones of the shoot (Meenaksh et al., 2001). Moore (1989) stated that cell division alone does not result in growth and so stimulation of cell division must be coupled with a normal or enhanced rate of cell elongation for there to be growth response to exogenous $\mathrm{GA}_{3}$.

In conclusion for surface sterilization of dormant finger tip explant of Curcuma longa L. Cv. Roma, surface sterilized with $70 \%$ Ethanol for 30 seconds followed by $0.1 \%$ $\mathrm{HgCl}_{2}$ for 11 minutes followed by $1 \% \mathrm{KCl}$ for 1 minute recorded highest percentage of survival $(90 \%)$ and aseptic culture (90\%) minimum days to bud emergence (11.33), maximum available days for bud elongation and each culture produced a single bud. MS medium supplemented with BAP (2.0, 2.5, $3.0, \mathrm{mg} / 1)$ in combination with NAA $(0.1$, $0.2,0.3 \mathrm{mg} / 1)$ with $\mathrm{GA}_{3}(0.2 \mathrm{mg} / 1)$ forced all the explants to produce a bud. MS medium supplemented with BAP $(3.0 \mathrm{mg} / 1)$, NAA $(0.2$ $\mathrm{mg} / 1)$ and $\mathrm{GA}_{3}(0.2 \mathrm{mg} / 1)$ produced longer buds $(0.7 \mathrm{~cm})$ from the dormant finger tip explant of $C$. longa cv. Roma. 


\section{References}

Beura, S. 1998. In vitro multiplication, Agrobacterium mediated transformation and post harvest handling of spikes in Gladiolus. Ph. D. Thesis, G.B.P.U.A.T., Pantnagar, 220.p.

Gomathy, V., Anbazhagen, M. and Arumugam, K. 2014. In vitro propagation of Curcuma longa (Turmeric). Int. J. Res. Plant Sci., 4(1): 30-33.

Gomez, K.A. and Gomez, A.A. 1984. Completely Randomized Design, In: Statistical procedures for Agricultural Research, $2^{\text {nd }}$ Edn. John Wiley and Sons, New York, 8-20.

Hussey, G. 1976. Propagation of Dutch iris by tissue culture. Scientia Hort., 3: 21-28.

Krishnamurthy, M.N., Padma, Bai. R., Natarajan, C.P. and Kuppuswamy, S. 1975. Colour content of turmeric varieties and studies of on its processing. J. Fd. Sci. Technol., 12: 12-14.

Meenakshi, N., Sulikeri, G.S., Krishnamoorthy, V. and Hegde. R.V. 2001. Standardization of chemical environment for multiple shoot induction of turmeric (Curcuma longa L.) for in vitro clonal propagation.
Crop Res. Hisar., 22(3): 449-453.

Moore, T.C. 1989. Cytokinin. In: Biochemistry and physiology of plant hormones. Narosa Publishing House, New Delhi: 159-195.

Nadgauda, R.S., A.F. Mascarenhas, R.R. Hendre and V. Jagannathan. 1978. Rapid multiplication of turmeric (Curcuma longa Linn.) Plants by tissue culture. Indian J. Expt. Biol., 16: 120-122.

Palai, S.K., Rout, G.R., Samantaray, S. and Das. P. 2000. Bio-chemical changes during in vitro organogenesis in Zingiber officinale Rosc. J. Plant Biol., 27(2): 153-160.

Rahman, M.M., Amin, M.N., Hajan, H.S. and Ahmed, R. 2004. In vitro regeneration of plantlets of Curcuma longa Linn. A valuable spice plant in Bangladesh. Asian J. P1. Sci., 3(3): 306-309.

Salvi, N.D., George, L. and Eupen, S. 2002. Micropropagation and field evaluation of micropropagated plants of turmeric. Plant Cell Tissue and Organ Culture, 68(2): 143-151.

Sunitibala, H., Damayanti, M. and Sharma. G.J. 2001. In vitro propagation and rhizome formation in Curcuma longa Linn. Cytobios, 105(409): 71-82.

\section{How to cite this article:}

Beura, S., A. Sahu, S. Rout, R. Beura and Jagadev, P.N. 2017. Standardization of Plant BioRegulators for In Vitro Shoot Proliferation of Curcuma longa L. Cv. Roma. Int.J.Curr.Microbiol.App.Sci. 6(5): 386-394. doi: http://dx.doi.org/10.20546/ijcmas.2017.605.044 